\section{Prof. J. A. Hanley}

The death of Prof. J. A. Hanley on April 10 occurred after several years of physical handicap, gallantly borne with the help of his devoted wife, following a breakdown in health he suffered in the post-war years. $\mathrm{He}$ has been living during this period of retirement from his academic career in Applethwaite, near Keswick. His last appointment was that of professor of agriculture and rural economy in King's College, University of Durham, Newcastle upon Tyne, where he directed the work of the School of Agriculture and Cockle Park (then Northumberland County Experimental Station, now owned by the College) from 1931 until 1947.

Hanley, who received his school education at Wakefield Grammar School, served later in the county of his birth and forbears as lecturer in agricultural chemistry and advisory chemist in the University of Leeds. Prior to this appointment he had obtained the degree of Ph.D., University of Munich, as well as becoming an associate of the Royal College of Science, for which he studied in London. Before going to Leeds he had been engaged in research at Rothamsted, and was Board of Agriculture Research Scholar during 1912-14. From Leeds be went as professor of agriculture and chief advisory officer in the University of Bristol, where he served from 1924 until 1927, whence he became principal of the Royal Agricultural College at Cirencester, where he continued during 1927-31. His appointment to the chair of agriculture at Newcastle-in succession to the famed Somerville, Middleton and Gilchrist-was made in 1931.

There is no doubt that he experienced much satisfaction from the opportunities afforded him in the scientific directorship of Cockle Park-an office which devolves on the professor of agriculture in King's College-for Hanley's major interest in agriculture was the subject of grassland management. As early as 1927 he was the joint author with Prof. R. G. Stapledon of the book "Grass Land : its Management and Improvement", published by the Oxford University Press, and in subsequent years he was responsible for the Ministry of Agriculture's well-known bulletin on "Grassland", as well as for several of the Ministry's leaflets on various aspects of the same subject. He was a leading spirit in the national campaign for grassland improvement, taking a prominent part as judge and adviser in the grassland competitions organized in the four northern counties of England during the early 'thirties.

While giving much attention to grassland, especially to the then recent developments in its utilization as dried grass and silage, in which subject he carried out early investigations at Cockle Park, Hanley had a wide knowledge of agriculture and agricultural education. In a volume of essays presented to Sir Daniel Hall on "Agriculture of the 20th Century", published in 1939, Hanley's fine contribution was a comprehensive study entitled "Agricultural Education in College and County".

Among his original contributions when at King's College was a survey of agriculture in the Northern Province (Counties Durham, Northumberland, Cumberland and Westmorland), made possible by a financial grant given by the Right Hon. David Lloyd George. Although this was a comparatively quick survey, the report published in 1936 gives an informative account of the agrieulture of the area which for the purpose of the survey was divided into twenty districts; Hanley being assisted in this extensive project by two of his students, Messrs. Boyd and Williamson.

As in the case of his predecessors mentioned in the chair of agriculture, King's College, he formed many mutually helpful friendships with northern farmersas, for example, D. J. Brown of West Learmouth, and J. B. Barr of Pressen-the study of whose farms, and discussion of changes in management, resulted in his contribution to the Journal of the Royal Agricultural Society of England, entitled "Tweedside Farming Enterprises", which itself is a typical example of the wide range of subjects on which he wrote for various journals. In his latter years he was editor of a series of four volumes published by Caxton in November 1949, under the title of "Progressive Farming'.

During the Second World War, from 1940 onwards, he became the Ministry of Agriculture's liaison officer for the northern counties in connexion with the food production campaign.

From my personal knowledge as a colleague for the period of his professorship at King's College, I knew him to be a very good teacher, whose courses of lectures on soils and geology are remembered. $\mathrm{He}$ showed a greatly appreciated interest in the social and athletic activities of his students, being inter alia a keen supporter of their Rugby achievements, to which a photograph (still hanging in the Dean's private room in the School of Agriculture) bear's testimony showing him surrounded by members of the team. No one who knew him intimately could fail to be aware of his emphasis on efficiency and his keen interest in his work as a teacher and adviser on agriculture, and of his continuous desire to make his contribution to the progress of that distinctive movement in the present century towards the improvement in management of the grassland of Great Britain.

H. Cecil Pawson

\section{Dr. F. Jones}

Dr. Francis Jones, T.D., died suddenly at Crowborough on February 28

Francis Jones was born at Belper, Derbyshire, in 1887. $\mathrm{He}$ was educated at Wirksworth Grammar School, graduated at the University of London, and later took his Ph.D. in geology. He was commissioned as a lieutenant in the Royal Engineers during the First World War and served in France, Gallipoli and Egypt. He taught as a science master, first in Leicester and then from 1929 until 1947 at St. Dunstan's College, London, where he served as commanding officer of the Officers Training Corps for eight years. During this period he also acted as head of the Department of Geology at the Northern Polytechnic. Between 1926 and 1936 he published a number of papers on his researches on the petrology of the Pre-Cambrian rocks of Charnwood Forest.

His love of geology and young people coupled with his tremendous energy would not allow him to retire, and in 1947, at the age of sixty, he joined the staff of the Geology Department of the Imperial College of Science and Technology, where he remained until 1958 ; at the same time he continuod until his death his teaching at the Northern Polytechnic. In the lecture theatre and the laboratory he was insistent on fundamentals. Influenced by his great friend, the late Dr. Alfred Brammall, he brought his knowledge of chemistry to bear on theoretical aspects of mineralogy and petrology, and his lectures and discussions on 